\title{
Effect of Fascial Distortion Model on the Pain and Movement of Neck Patient
}

\author{
Min Kyu Kim¹, Woo Jin Lee ${ }^{2}$ \\ 'Dawoom Rehabilitation Center, Pohang; ${ }^{2}$ Department of Physical Therapy, Gangneung Youngdong University, Gangneung, Korea
}

Purpose: This study compared the effectiveness of three methods, fascial distortion model (FDM), myofascial release (MFR), self-myofascial release (SMR), on the neck range of motion and pain.

Methods: In this study, the collected data were processed statistically using SPSS version 22.0 for Windows. Descriptive statistics were used to analyze the general characteristics of the subjects. Repeated measure ANOVA was conducted to analyze the range of motion of the neck of the group and VAS, and Contras was used to see the difference in significance over time. One-way ANOVA was used to compare the differences among the groups and a post-hoc test was used. The significance level $(\alpha)$ was 0.05 .

Results: In the range of motion, the flexion and extension of the neck, right rotation, and left rotation were significantly different in the SMR, FDM, and MFR groups. The right lateral flexion showed significant differences in the FDM, MFR, and SMR groups. The VAS was similar in the groups at 2 and 4 weeks, but there was a significant difference among the FDM, MFR, and SMR groups at 6 weeks.

Conclusion: In this study, MFR and MSR as well as FDM were effective in controlling the range of motion and pain control of the neck. Further studies will be needed to determine the effects of long-lasting treatments other than pain control. These studies and the present study will be used as a basis for ongoing research into the duration and method of application for musculoskeletal therapies.

Keywords: Fascial distortion model, Myofascial release, Self-myofascial release, Neck pain

\section{서 론}

현대사회는 정보화의 지속적인 발전으로 서서하는 작업보다는 장시 간의 컴퓨터 작업, 운전, 스마트폰 사용 등 앉아서 근무하는 작업 환 경이 많아지면서 신체적, 정신적 스트레스의 축적과 근육의 과도한 긴장으로 두통뿐만 아니라 목, 어깨 등의 근.뼈대계통의 이상과 통 증을 호소하는 빈도가 점차적으로 증가되고 있다. 또한 작업과정에 서의 바르지 못한 자세와 특정 움직임의 반복, 운동 부족 등은 통증 을 악화시키고 관절의 원활한 움직임을 제한하여 일상생활과 업무 의 효율성을 저하시킨다.1-3

목은 많은 연부조직과 관절로 구성되며 굽힘과 폄, 가쪽 굽힘, 돌림 등의 다양한 움직임이 가능한데, 목 통증이란주변 조직의 통증과 기 능제한을 뜻한다. ${ }^{4} \mathrm{Lee}$ 등 ${ }^{5}$ 은 목 통증은 비 특이성과 특이성으로 분류 되며, 비 특이성은 바르지 못한 자세의 습관이 원인이며, 특이성은 퇴 행성 변화와 외상 등이 원인이라고 보고하였으며, $\mathrm{Oh}$ 와 $\mathrm{Yoo}^{6}$ 는 비 특 이성 목 통증은 관절주머니와 인대 등을 포함하여 관절 내의 병리적
상태 변화가 없는 기능 장애를 나타내며, 몸통과 팔다리 통증의 대부 분은 관절의 기능 장애를 동반하며 관절의 기능에 문제가 있는 경우, 움직임을 할 때 정상적인 관절주머니 내부에서 움직임이 제한되기 때문에 통증이 발생된다고 제시하였으며, 이 중 연부조직 손상에 의 한 것이 전체의 $87.5 \%$ 를 차지한다고 보고하였다.

급성 통증은 질환의 원인이 제거되면 완화되지만 지속적인 사용 으로 인해 만성 통증이 지속되고 근막 내의 통증유발점(trigger point) 이 근막 경선을 따라 도미노 현상처럼 나타나는데 이 현상을 근막통 증증후군이라 한다.-11 근막통증증후군(myofascial pain syndrome)은 생애 중 한 번 이상 경험하는 질환으로 증상이 없는 성인 여성과 남성 에서 각각 $54 \%, 45 \%$ 의 잠재성 통증유발점이 존재하며, 근뼈대계의 통증을 유발시키는 가장 흔한 원인이라고 하였다. ${ }^{12}$

Punnett 등 ${ }^{13}$ 은 부적절한 자세나 근육의 과 사용, 대사장애, 정신적 스트레스 등에 의해 유발될 수 있고, 특히 근육에 부하가 걸리는 일 과 관련이 있는 직업에 종사하는 경우 매우 반복적이거나 정적으로 스트레스가 가해져 목과 어깨 주변의 통증이 원인이 되어 다양한 문
Received Jan 3, 2019 Revised Feb 13, 2019

Accepted Feb 14, 2019

Corresponding author Woo-Jin Lee

E-mail marin66@hanmail.net
Copylight (C2019 The Korean Society of Physical Therapy

This is an Open Access article distribute under the terms of the Creative Commons Attribution Non-commercial License (Http:// creativecommons.org/license/by-nc/4.o.) which permits unrestricted non-commercial use, distribution, and reproduction in any medium, provided the original work is properly cited. 
제점을 발생시킨다고 보고하였다. 통증조절을 위해 임상에서 대중적 으로 적용되는 치료방법으로는 온열 및 전기치료, 근막변형모델(fascial distortion model, $\mathrm{FDM}$ ), 관절가동기법, 근막이완기법(myofascial release, MFR), 자가근막이완(self myofascial release, SMR) 등이 있다.1,14-16

근막이완기법은 긴장된 근막조직과 근육의 최대 이완을 촉진시키 는 방법으로 임상에서 주로 통증조절에 적용되고 있으며, ${ }^{17}$ 근막을 통합된 전체조직으로 간주하여 상호관련성이 있는 개념으로 보고 머리.엉치 치료법과 근막운동 촉진법으로 특정 신체의 부분적인 제 한은 신체의 전반적인 제한이라는 것으로 생각되어 전체적인 계통으 로 다룬 치료 기법이다.18

자가근막이완은 근막과 신경계의 개선 및 이완을 위해 스스로 수 행하는 것으로, 적용하고자 하는 부위에 도구를 사용하여 압력을 통 해 근막과 힘줄에 분포하는 고유수용기가 자극되거나 흥분이 감소 되어 근막과 근육의 긴장을 완화시키는 방법이다. ${ }^{19}$ 통증유발점(trigger point)으로 인한 통증을 경감시키거나 자율신경계를 자극하여 근 육의 골지건 기관(golgi tendon organ)의 근방추(muscle spindle)의 흥 분을 감소시키기 위해 적용할수 있다..$^{20}$

근막변형모델은 근막의 주요 역할이 관절과 그 주변을 보호하는 것이고, 신체 조직은 다양한 형태의 근막 변형으로 영향을 받으며, 이 러한 근막들이 부하를 받거나 외부의 충격으로 인해 변형이 생겨 통 증을 유발한다고 하였으며, 근막의 변형 형태를 몇 가지로 구분하였 는데, 그 종류는 밴드형 근막변형(trigger bend distortion), 코일형 변형 (cylinder distortion), 접힘 변형(folding distortion), 인대, 힘줄 등의 줄무 늬 근막의 변형(continuumdistortion) 등으로 구분된다고 하였으며, 근 막의 변형 부분에 강한 압력을 적용하여 이를 원래 형태로 되돌리는 치료기법을 사용한다. 이처럼 임상에서 다양한 근막 치료방법이 시 행되고 있으며, 본 연구에서는 목과 어깨의 통증을 호소하는 환자를 대상으로 근막변형모델치료, 근막이완기법, 자가근막이완을 각 그룹 별로 적용하여 목의 관절절가동범위 및 통증 변화를 비교 분석하여 어떠한 영향을 미치는지 알아보고자 연구를 시행하였다.

\section{연구방법}

\section{1. 연구 대상자}

본 연구의 대상자들은 목과 어깨에 통증을 호소하는 자로 2016년 12 월부터 2017년 1월까지 2개월에 걸친 기간 동안에 A시 소재의 C병원 을 방문한 환자들 중 선정하였다. 연구에 참여한 모든 대상자들은 연 구의 절차 및 목적, 잠재적 이점, 위험성과 관련된 구체적인 설명을 들 은 후 동의서를 작성한 후 자발적으로 본 연구에 참여하였으며, 본 연 구에 참여한 대상자는 목과 어깨에 통증을 가진 환자 45 명으로 구성 되었다. 대상자의 일반적인 특성은 다음과 같다(Table 1). 실험대상자
Table 1. General characteristics of subjects

$(\mathrm{N}=45)$

\begin{tabular}{lcccc}
\hline Subjects & FDM & MFR & SMR & Total \\
\hline Gender & & & & \\
Male & 7 & 8 & 7 & 22 \\
Female & 8 & 7 & 8 & 23 \\
Age (yr) & $36.60 \pm 6.06$ & $40.73 \pm 5.47$ & $34.07 \pm 6.10$ & $37.13 \pm 6.38$ \\
Height (cm) & $169.06 \pm 7.38$ & $171.13 \pm 9.19$ & $170.20 \pm 9.81$ & $170.13 \pm 8.69$ \\
Weight (kg) & $65.73 \pm 14.44$ & $67.60 \pm 16.53$ & $66.13 \pm 14.55$ & $66.49 \pm 14.88$
\end{tabular}

Values are mean $\pm S D$.

의 분류는 선정에 대한 편견을 최소화하기 위해 무작위 분배프로그 램인 random allocation software 1.0을 사용하여, ${ }^{21}$ 그룹 간 15명씩 무 작위 배치하였다.

그리고 목에 추간판탈출증이 있는 자, 피부질환 및 기타 퇴행성 질 환 등의 신체 구조적 결함이 있는 자, 실험에 영향을 줄 수 있는 다른 치료를 받은 경험과 약물 또는 주사, 수술 등을 받은 자 및 목과 어깨 통증 이외의 기타 질환을 가진 자의 경우 대상자에서 제외를 하였다.

\section{2. 측정도구 및 실험방법}

\section{1) Goniometer}

목 관절의 가동범위 측정을 위해 goniometer (Anymedi, Korea)를 사용 하였으며, 대상자는 중립 자세를 취하고 몸통의 다른 부위에 의해 영 향을 받지 않도록 하였다. 대상자는 설정자세를 위해 설정위치에서 3 초간 유지하였고, 실험자는 대상자의 학습효과를 제거하기 위해 재위 치 연습 후 1 분간의 쉬는 시간을 가지도록 하였으며,22,23 측정 간에 쉬 는 시간은 10 초로 정하였다. 모든 동작은 능동적으로 시행하였으며 굽힘은 대상자의 턱을 가슴에 최대한 붙이도록 하고, 폄은 턱을 최대 한 뒤로 젖히도록 하여 측정하였다. 가쪽 굽힘은 귀가 어깨부위에 닿 도록 하였으며, 돌림은 최대로 돌린 상태에서 측정하였다. 모든 관절 가동범위의 각도는 최초 0 도에서 시작하여 측정하였으며, 측정 순서 는 폄, 왼쪽과 오른쪽 가쪽 굽힘, 굽힘, 왼쪽과 오른쪽 돌림 순으로 하 였다. 그리고 측정은 2 회 반복측정 한 후 평균값을 사용하였다.

\section{2) 시각적 상사척도(visual analogue scale, VAS)}

본 연구에서는 치료 전과 후의 주관적인 통증 수준을 측정하기 위해 $\mathrm{VAS}$ 를 사용하였다. ${ }^{24}$ 이 검사 도구는 환자가 느끼는 주관적인 통증 정 도를 $100 \mathrm{~mm}$ 의 선 위에 주관적으로 표시하는 방식으로 점수화하기 가 용이하며, 척도의 타당도와 신뢰도가 높아 임상이나 연구에서 자 주 이용되고 있다. ${ }^{25}$ 시각적 상사척도의 검사방법은 왼쪽 끝인 0 은 통 증이 전혀 없는 상태, 오른쪽 끝인 10 의 위치는 통증이 극심한 상태 를 의미하며, 통증의 정도가 수치화, 객관화된 검사방법이다. ${ }^{26}$ 


\section{3. 실험절차}

\section{1) 실험방법}

본 연구의 중재방법으로 적용된 근막변형모델치료, 근막이완기법, 자 가근막이완은 아래와 같은 방법을 사용하였으며, 근막의 충분한 이완 효과가 나타날 수 있도록 1 회당 15 분 이내로 주 2 회, 총 4 주간 실시하였 다. 또한 연구의 신뢰성을 높이기 위해 집단 별로 임상경력 5 년차 이상 인 물리치료사 1 명이 중재하였으며, 구체적인 방법은 다음과 같다.

\section{(1) 근막변형모델(FDM)}

근막변형모델치료는 환자의 주관적인 표현인 신체언어(body language)를 파악하여 진단을 내리고, 치료사의 손으로 문제점을 해결 하는 새로운 개념의 진단과 치료방법이다. 오늘날에는 신체 구조물 의 손상으로 동반되는 염증을 통증의 주요 생성 기전이라고 알려져 있으나, 근막변형모델 치료에서는 다른 측면으로 근막의 변형 형태가 통증의 결정적인 요인이라고 하였다. ${ }^{14}$ 근막변형모델은 통증을trigger bands (TB), herniated trigger points (HTP), continuum distortion (CD), folding distortion (FD), cylinder distortion (CYD), tectonic fixations (TF) 으로 여섯 가지 근막 변형 유형으로 설명하고 있으며, 변형부위에 물
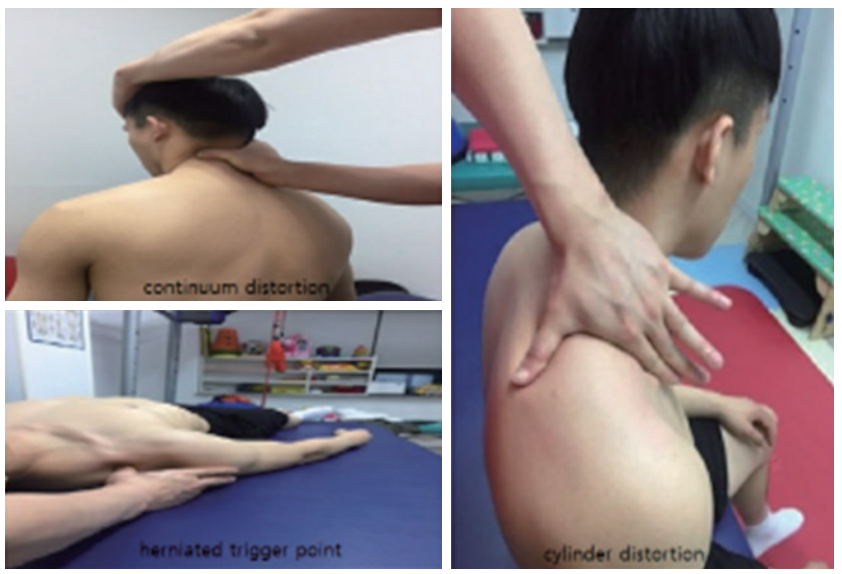

리적인 강한 압력을 가하여 유착을 제거하는 것으로 손상부위의 섬 유를 풀어주고, 찢어진 섬유를 다시 결합시키는 방법이다. ${ }^{14}$

본 연구에 사용한 치료법은 trigger band 치료이다. Trigger band는 뒤틀리거나 분리되고 혹은 찢어지거나 주름진 형태를 보이는 근막의 상태를 말한다. 이와 관련된 환자의 표현은 타는 듯 하는 또는 당기는 듯 하는 통증으로 표현한다. 근막변형모델은 물리적인 강한 압력을 가하여 유착을 제거하는 것으로 손상부위의 섬유를 풀어주고, 찢어 진 섬유를 다시 결합시키는 것이다. ${ }^{14}$

경부에서의 trigger band의 치료방법은 4가지 라인(line)이 있다. 첫 번째 라인은 뒤통수에서 시작하여 어깨 양쪽 어깨돌기 부위의 위등 세모근까지 왼쪽과 오른쪽에 연결되는 선, 두번째 라인은 뒤통수에 서 시작하여 어깨뼈 위각부분까지 왼쪽과 오른쪽에 연결되는 선, 그 리고 세번째 라인은 뒤통수에서 시작하여 목뼈 왼쪽과 오른쪽에 연 결되는 선을 따라 엄지손가락을 이용한 일차적인 치료를 적용한다. 네번째 라인은 꼭지돌기에서 시작하여 복장뼈 부위까지 연결되는 선 을 따라 치료를 적용하며, 통증을 느끼는 관절부위에 조직이 녹는 듯 하는 느낌이 들 때까지 엄지손가락을 압박한 치료를 적용한다. 그리 고 마지막으로 cylinder distortion이라는 치료방법을 사용한다. cylinder distortion은 통증을 호소하는 부위를 손바닥 전체의 강한 압박을 이용하여 넓게(squeeze) 강하게 쓸어내린다(Figure 1).

\section{(2) 근막이완기법(MFR)}

근막이완기법은 1948년에 Dr. Janet G, Travell에 의해 처음 소개되었으 며, ${ }^{27}$ 본 연구에서 근막이완 기법의 적용은 목 이완(cervical stretch), 뒤 통수 이완(occipital release) 및 위등세모근 이완(upper trapezius release) 방법을 사용하였다. 목 이완 방법은 대상자를 테이블 위에 바로 누운 자세(supine)를 하고 연구자의 두 손을 환자의 머리를 받치고 목뼈를 부드럽게 견인하여 근막이 충분히 늘어나는 것이 손끝에서 느껴질 때 서서히 힘을 빼고 이완시켰으며, 뒤통수 이완 방법은 두 손가락 끝 부분을 이용하여 대상자의 뒤통수부위를 받쳐 아주 작은 압박으로

Figure 1. Fascial distortion model

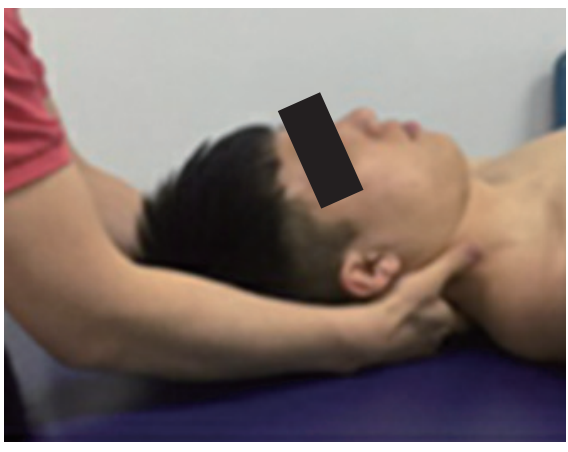

Cervical stretch

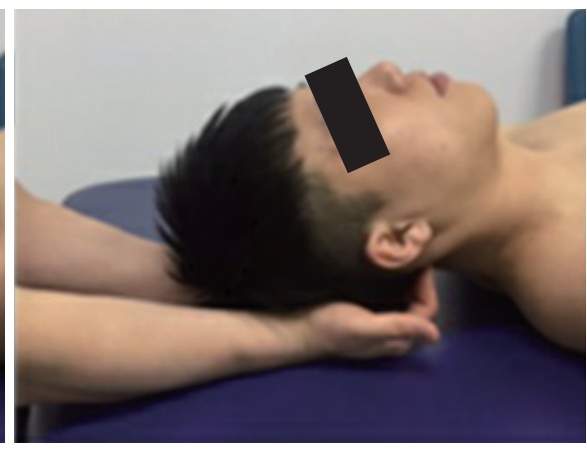

Occipital release

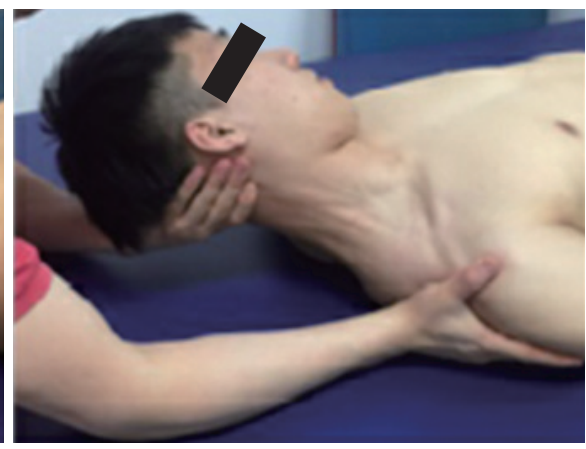

Upper trapezius release

Figure 2. Myofascial release 

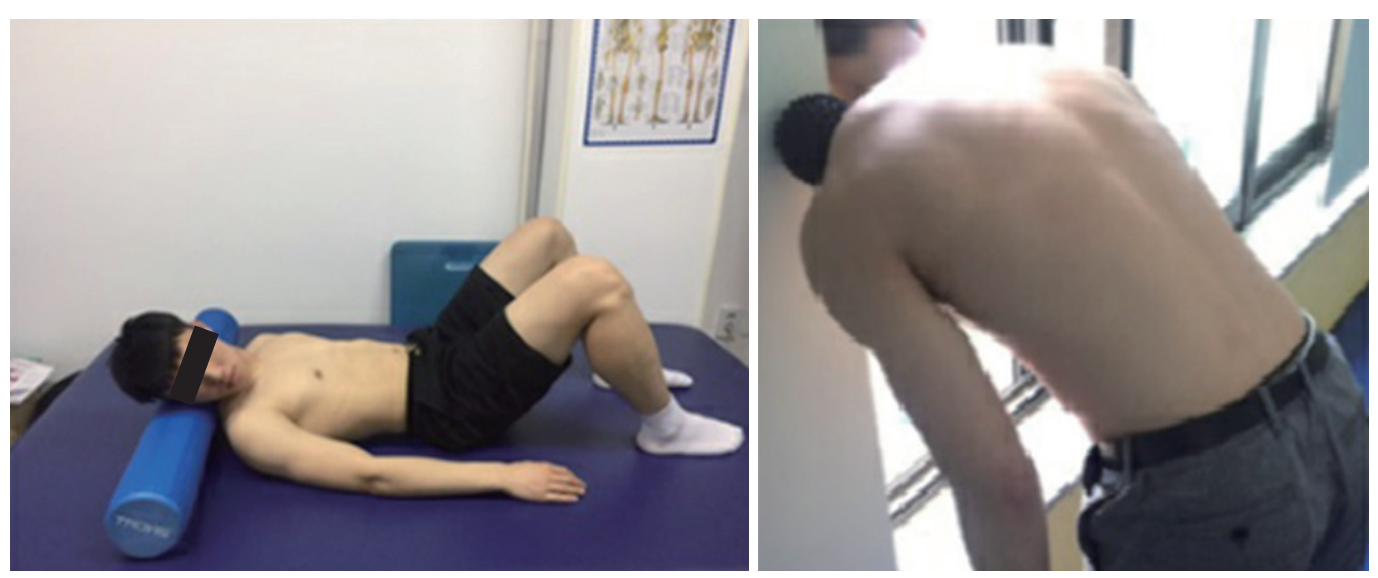

Figure 3. Self myofascial release

Table 2. Comparison of movement among the three groups

(unit: angle)

\begin{tabular}{|c|c|c|c|c|c|c|c|}
\hline & Subjects & Pre-test (1) & 2-weeks (2) & 4-weeks (3) & Follow up (4) & $\mathrm{F}$ & contrast \\
\hline \multirow[t]{5}{*}{ Flex } & FDM (a) & $36.80 \pm 2.83$ & $39.33 \pm 2.53$ & $40.00 \pm 2.62$ & $40.60 \pm 3.39$ & $3.53^{*}$ & $1<2=3<4$ \\
\hline & MFR (b) & $35.73 \pm 3.26$ & $36.00 \pm 3.25$ & $37.73 \pm 2.52$ & $36.93 \pm 2.58$ & $2.91^{*}$ & $1<2=3<4$ \\
\hline & $\operatorname{SMR}(c)$ & $35.47 \pm 2.07$ & $40.27 \pm 1.44$ & $41.27 \pm 1.75$ & $39.07 \pm 2.44$ & $2.98^{*}$ & $1<2=3<4$ \\
\hline & $\mathrm{F}$ & 1.85 & 11.9 & 8.86 & 6.33 & & \\
\hline & post-hoc & & $b<a<c$ & $b=c<a$ & $b=c<a$ & & \\
\hline \multirow[t]{5}{*}{ Ext } & FDM (a) & $51.07 \pm 5.66$ & $56.67 \pm 6.36$ & $58.00 \pm 6.92$ & $57.90 \pm 7.16$ & $5.11^{*}$ & $1<2<4<3$ \\
\hline & MFR (b) & $48.50 \pm 5.15$ & $49.87 \pm 5.14$ & $52.13 \pm 4.72$ & $51.60 \pm 4.81$ & $3.91^{*}$ & $1<2<4<3$ \\
\hline & SMR (c) & $49.20 \pm 3.08$ & $51.73 \pm 2.50$ & $53.47 \pm 1.73$ & $52.40 \pm 1.69$ & $2.96^{\star}$ & $1<2<4<3$ \\
\hline & $\mathrm{F}$ & 2.01 & 17.98 & 18.33 & 19.16 & & \\
\hline & post-hoc & & $b<a<c$ & $\mathrm{~b}=\mathrm{c}<\mathrm{a}$ & $\mathrm{b}=\mathrm{c}<\mathrm{a}$ & & \\
\hline \multirow[t]{5}{*}{ Rt.rot } & FDM (a) & $60.60 \pm 3.81$ & $66.00 \pm 2.98$ & $68.07 \pm 1.44$ & $67.47 \pm 1.41$ & $25.29^{\star}$ & $1<2<4<3$ \\
\hline & MFR (b) & $59.47 \pm 4.09$ & $61.13 \pm 3.46$ & $63.80 \pm 2.62$ & $62.07 \pm 2.22$ & $4.85^{\star}$ & $1=2<4<3$ \\
\hline & $\operatorname{SMR}(c)$ & $62.33 \pm 3.33$ & $62.73 \pm 2.99$ & $64.20 \pm 2.57$ & $62.47 \pm 2.50$ & 1.35 & - \\
\hline & $\mathrm{F}$ & 2.21 & $9.30^{+}$ & $16.06^{+}$ & $30.93^{+}$ & & \\
\hline & post-hoc & & $\mathrm{b}=\mathrm{c}<\mathrm{a}$ & $\mathrm{b}=\mathrm{c}<\mathrm{a}$ & $\mathrm{b}=\mathrm{c}<\mathrm{a}$ & & \\
\hline \multirow[t]{5}{*}{ Lt.rot } & FDM (a) & $61.27 \pm 3.20$ & $65.80 \pm 3.14$ & $68.53 \pm 1.81$ & $68.27 \pm 1.62$ & $26.15^{\star}$ & $1<2<3=4$ \\
\hline & MFR (b) & $60.40 \pm 5.17$ & $62.27 \pm 3.95$ & $63.93 \pm 3.20$ & $62.20 \pm 3.14$ & 2.00 & - \\
\hline & SMR (c) & $61.07 \pm 3.61$ & $61.87 \pm 3.18$ & $63.27 \pm 2.49$ & $62.07 \pm 2.05$ & 1.47 & - \\
\hline & $\mathrm{F}$ & 0.18 & $5.91^{+}$ & $18.79^{+}$ & $33.73^{+}$ & & \\
\hline & post-hoc & & $\mathrm{b}=\mathrm{c}<\mathrm{a}$ & $\mathrm{b}=\mathrm{c}<\mathrm{a}$ & $b=c<a$ & & \\
\hline \multirow[t]{5}{*}{ Rt.sb } & FDM (a) & $32.47 \pm 2.26$ & $35.07 \pm 1.49$ & $36.00 \pm 1.20$ & $35.83 \pm 1.25$ & $14.52^{\star}$ & $1<2<4<3$ \\
\hline & MFR (b) & $33.87 \pm 3.89$ & $34.13 \pm 2.26$ & $35.27 \pm 1.53$ & $34.53 \pm 1.51$ & 0.89 & - \\
\hline & SMR (c) & $35.27 \pm 2.71$ & $36.00 \pm 2.10$ & $36.17 \pm 1.53$ & $35.43 \pm 1.10$ & 2.98 & $1=4<2=3$ \\
\hline & $\mathrm{F}$ & 3.19 & $3.33^{+}$ & $6.01^{+}$ & $3.69^{+}$ & & \\
\hline & post-hoc & & & $b<a=c$ & & & \\
\hline \multirow[t]{5}{*}{ Lt.sb } & FDM (a) & $33.33 \pm 1.59$ & $34.87 \pm 1.73$ & $36.47 \pm 1.41$ & $35.94 \pm 1.39$ & $11.57^{\star}$ & $1=2<3=4$ \\
\hline & MFR (b) & $33.53 \pm 2.13$ & $34.53 \pm 1.96$ & $35.33 \pm 1.29$ & $34.60 \pm 1.35$ & $2.88^{*}$ & $1=2=4<3$ \\
\hline & SMR (c) & $35.00 \pm 2.42$ & $35.60 \pm 1.96$ & $36.20 \pm 1.70$ & $35.67 \pm 0.82$ & 1.09 & - \\
\hline & $\mathrm{F}$ & 2.88 & 1.25 & 2.41 & $4.11^{+}$ & & \\
\hline & post-hoc & & & & $b<a=c$ & & \\
\hline
\end{tabular}

Flex: flexion, Ext: extension, Rt.rot: right rotation, Lt.rot: left rotation, Rt.sb: right side bending, Lt.sb: left side bending. ${ }^{*} \mathrm{p}<0.05$.

들어 올려 손끝에서 이완이 느껴질 때까지 기다리며, 압박의 정점에 서 15 초 정도 정지한 후 천천히 힘을 빼고 이완시켰다. 위등세모근 이
완 방법은 근막이 자극되도록 연구자의 손을 머리뼈에 대고 등세모 근 위 섬유의 몸 쪽을 받쳐 손가락 끝을 이용해 이완하고자 하는 방 
Table 3. Comparison of VAS among the three groups

(unit: score)

\begin{tabular}{lcccccc}
\hline Subjects & Pre-test (1) & 2-weeks (2) & 4-weeks (3) & Follow up (4) & F & contrast \\
\hline FDM (a) & $5.87 \pm 0.45$ & $4.40 \pm 0.40$ & $3.00 \pm 0.36$ & $3.07 \pm 0.33$ & $16.300^{*}$ & $1>2>3=4$ \\
MFR (b) & $5.07 \pm 0.45$ & $4.60 \pm 0.40$ & $4.07 \pm 0.36$ & $4.27 \pm 0.33$ & 0.452 & - \\
SMR (c) & $5.07 \pm 0.45$ & $4.53 \pm 0.40$ & $4.07 \pm 0.36$ & $4.60 \pm 0.33$ & 0.272 & - \\
F & 1.053 & 0.066 & 2.849 & $5.898+$ & & \\
Post-hoc & & & & $\mathrm{a}<\mathrm{b}=\mathrm{c}$ & \\
\hline
\end{tabular}

FDM: fascial distortion model, MFR: myofascial release, SMR: self myofascial release. * $p<0.05$.

향으로 부드럽게 압박을 가하고 압박의 정점에서 15 초 정도 정지한 후 천천히 힘을 빼고 이완 적용하였다(Figure 2).

\section{(3) 자가근막이완(SMR)}

본 연구에서 적용된 자가근막이완은 폼롤러(foam roller)와 라크로스 볼(lacrosse-ball)을 사용하여 근막의 충분한 이완 효과가 나타날 수 있도록 1 회당 15 분 이내로 시행하였다. 대상자는 바로 누운 자세(supine)에서 베개를 사용하듯 목 뒷부분에 폼롤러를 대고 압박을 유지 하여 목을 좌우로 돌림 하면서 주변근육을 이완한 후, 옆으로 누운 자세로 겨드랑이 아래 넓은등근 부위에 도구를 놓고 위아래로 굴린 다. 단, 통증이 심한 경우 굴리지 않고 압박만 가하도록 하였으며, 라 크로스 볼을 이용하여 선 자세 또는 허리를 굽힌 자세에서 기둥을 이 용하여 통증유발점 부위에 압박을 가하도록 하였다(Figure 3).

\section{4. 자료분석}

본 연구에서는 수집된 자료를 윈도우용 SPSS version 22.0을 사용하 여 통계처리 하였으며, 대상자의 일반적인 특성을 분석하기 위해 기 술 통계를 실시하였다. 그룹 내 목의 관절 가동범위와 시각적 상사척 도에 분석을 위해 반복측정분산분석(repeated measure ANOVA)을 하 였으며, 시간에 따른 유의성 차이를 보기 위하여 contras를 사용하였 으며, 그룹 간의 차이를 보기 위하여 사후검정으로 post-hoc을 사용 하여 처리하였다. 유의수준(a)은 0.05 로 하였다.

\section{연구 결과}

\section{1. 목 관절가동범위 분석}

시간에 따른 반복측정에서 그룹 내 효과 검증 결과 목의 굽힘과 폄은 세 그룹에서 유의하게 증가를 하였고, 오른쪽 회전은 FDM그룹과 $\mathrm{MFR}$ 그룹 내에서 유의한 증가를 보였으며, 왼쪽 회전은 FDM그룹에 서만 유의한 증가를 보였다 $(\mathrm{p}<0.05)$. 그리고 왼쪽측방굴곡은 FDM그 룹과 MFR그룹에서 오른쪽 측방굴곡은 FDM그룹과 SMR그룹에서 유의한 증가를 보였다 $(\mathrm{p}<0.05)$. 또한 치료 종료 후 추적 측정에서 관 절가동범위가 감소하는 것을 보이고 있으나, 치료 전 보다 유의한 상
승효과를 보이는 것으로 나타났다.

그룹 간 검증결과 2 주차일 때 목의 굽힘, 신전은 세 그룹에서 유의 한 차이를 보였고, 왼쪽 회전과 오른쪽 회전은 FDM그룹과 SMR그룹, $\mathrm{FDM}$ 그룹과 MFR그룹에서 유의한 차이를 보였다. 오른쪽 측방굴곡 은 FDM그룹과 MFR그룹, MFR그룹과 SMR그룹에서 유의한 차이를 보였다 $(\mathrm{p}<0.05)$. 그러나 측방굴곡에서는 통계적으로 유의한 차이를 보이지 않았다. 또한 4 주차일 때 목의 굽힘과 폄, 오른쪽회전, 그리고 왼쪽회전은 FDM그룹과 SMR그룹, $\mathrm{FDM}$ 그룹과 MFR그룹에서 유의 한 차이를 보였고, 오른쪽측방굴곡은 FDM그룹과 MFR그룹, MFR그 룹과 SMR그룹에서 유의한 차이를 보였다 $(\mathrm{p}<0.05)$. 6 주 후 경과 관찰 기간에서는 목의 굽힘과 폄, 오른쪽 회전, 그리고 왼쪽 회전은 FDM 그룹과 SMR그룹, FDM그룹과 MFR그룹에서 유의한 차이를 보였다 $(\mathrm{p}<0.05)$ (Table 2).

\section{2. 시각적 상사척도 분석}

시간에 따른 반복측정에서 그룹 내 효과 검증 결과 FDM그룹에서 유 의한 감소를 보였으며 $(\mathrm{p}<0.05)$, MFR그룹과 SMR그룹에서는 유의한 차이를 보이지 않았다. 그룹 간 검증결과 2,4 주차일 때는 유의한 차 이를 보이지 않았지만 6주 후 경과 관찰기간에는 FDM그룹과 MFR 그룹, $\mathrm{FDM}$ 그룹과 SMR그룹에서 유의한차이를 보였다 $(\mathrm{p}<0.05)$. 시각 적 상사척도의 그룹 간 비교 결과 모든 집단이 치료 전에 비해 치료가 진행될수록 점수의 감소가 나타났으며, 치료방법에 따른 집단 간 차 이는 유의하지 않았다( $\mathrm{p}>0.05)$. 치료 종료 후 추적 측정에서 FDM 그 룹과 비교하였을 때 MFR과 SMR 그룹의 점수가 더 높은 것으로 나타 났으며, 유의한 차이가 있었다 $(\mathrm{p}<0.05)$.

\section{고 찰}

현대의 산업 형태는 서비스업으로 점차 변화됨에 따라 작업형태가 좌식으로 변하여 목과 어깨에 부하량을 집중시켜 근. 뼈대계통의 기 능 장애와 통증 증가의 주된 원인이 된다. $28,29 \mathrm{Nam}$ 등 ${ }^{30}$ 은 장기간에 걸 쳐 통증과 염증이 지속되는 악순환이 일어나면 조직 내의 결절 형태 로 촉진되는 통증유발점이 생성되며, 근막통증증후군은 통증유발 
점으로 인하여 발생될 수 있는데 이는 근막의 손상이나 과부하에 의 해 발생되며 근 약화(weakness), 가동범위 제한 등의 기능장애, 자율 신경계 문제 등의 증상을 나타낼 수 있다고 하였다.9,31

현재의 근막이완기법으로 알려져 있는 유럽의 근막이완법(MFR) 은 19 세기 초에 체계화되었으며, ${ }^{27}$ 근막이완기법은 조직을 균형 있게 유도하며, 통증을 유발시키는 긴장된 조직을 이완하기 위한 기법이 며 긴장된 근막에 적용하면 혈류량이 증가되어 노폐물의 배출을 촉 진하고 통증 부위의 근막 평면을 재배열 하여 통증부위에 대한 긍정 적인 영향을 미친다고 하였다. ${ }^{32}$

자가근막이완(SMR)은 근육의 골지건 기관(golgi tendon organ)의 자극과 근방추(muscle spindle)의 흥분이 감소되는 형태로 이루어지 며, 근막 및 연부조직의 생체역학적인 특성에 영향을 미치는 것으로 알려지면서 임상에서 다양하게 활용되는 방법 중 하나이며, 가장 잘 알려진 효과로는 유연성의 향상, 유착의 감소, 근육 불균형의 교정, 통증의 감소, 혈류의 증가 등이 있다고 하였다. 15,32

근막변형모델(FDM)은 통증을 trigger bands (TB), herniated trigger points (HTP), continuum distortion (CD), folding distortion (FD), cylinder distortion (CYD), tectonic fixations (TF)으로 여섯 가지 근막 변형 유형으로 설명하고 있으며, 변형부위에 물리적인 강한 압력을 가하 여 유착을 제거하는 것으로 손상부위의 섬유를 풀어주고, 찢어진 섬 유를 다시 결합시키는 방법이다. ${ }^{14}$ 따라서 본 연구에서는 기존에 사용 하는 근막치료방법인 근막이완기법과 자가근막이완 그리고 최근에 소개된 근막변형모델을 적용하여 목의 관절가동범위 및 통증 변화 에 미치는 영향을 알아보고자 하였다.

본 연구에 참여한 대상자들은 목의 관절범위 제한과 통증에 높은 점수를 나타내고 있었으며, 4주간 치료 후의 변화에서 모든 집단에 서 관절가동범위 향상과 통증이 감소하는 것으로 나타났다. 본 연구 결과 FDM, MFR과 SMR 방법이 기존 연구에서 보고하였듯이 근막의 결절 지점에서 발생할 수 있는 교차 결합을 제거하여 고체 상태인 근 막의 점도를 액체 상태로의 변화시켜주어 근막의 유연성이 증가하였 으며, 근육과 힘줄의 구성 요소인 근방추와 골지건 기관, 중추신경계, 말초 신경계의 상태를 회복하고, 이완을 촉진하여 기능을 향상시킨 결과라고 생각된다. ${ }^{33,34}$

또한 $\mathrm{FDM}, \mathrm{MFR}, \mathrm{SMR}$ 방법으로 근막에 적용하는 치료가 긍정적인 효과를 보인 이유는 골지건 기관(golgi tendon organ, GTO)과 근방추 (muscle spindle)의 기능 때문이라고 생각된다. $\mathrm{Kim}^{35}$ 은 GTO는 장력이 발생되어 일정 문턱값 수준을 넘어서게 되면서 활성화되어 고위 중추 로 자극이 전달되며, 이러한 과정을 거치면 반사적으로 주동근과 협 력근의 운동 뉴런을 억제시켜 이완이 발생되며 길항근의 운동 뉴런을 흥분시켜 수축시키는 역 신장 반사(inverse myostatic reflex)를 일으킨 다고 하였고, GTO에서 발생되는 역신장 반사에 의해 일차적으로 근
막의 수축은 감소하게 되며, 그에 따라 대사산물은 감소될 수 있으며 이러한 대사산물의 감소에 대한 결과로 통증 감각의 구심성 섬유의 대한 흥분도 감소될 수 있다. 이는 근막 이완을 촉진하여 혈액이나 림 프의 흐름과 여러 조직에 영양소나 산소의 공급을 원활하게 하며, 노 폐물들을 조직에서 혈관으로 배출시켜 조직의 영양상태 개선하고, 주 변 조직을 활성화시켜 통증을 감소시켰기 때문이라고 생각된다

본 연구는 근막치료 방법의 차이가 목과 어깨통증 환자의 목의 관 절가동범위 향상 및 통증 변화에 미치는 영향을 파악하고자 실험집 단 간 다른 근막 치료방법을 적용함으로써 각 실험집단의 결과를 비 교 분석하여 가장 효과적이며 신속한 치료방법 및 효과를 제안하고 자 하였다. 그 결과 목의 관절가동범위 및 통증 조절에 MFR과 SMR 뿐 아니라 FDM도 효과적이라는 것을 확인할 수 있었다. 본 연구는 목과 어깨통증환자만을 대상으로 하였고 치료사 개인능력의 차를 가늠할 수가 없어 근막 치료의 결과를 일반화하기엔 제한이 있다. 향 후 근막 치료방법의 차이에 따른 적용기간 및 방법에 따른 장기적인 연구가 지속적으로 이루어져야 할 것이며, 임상과 기타 관련 연구들 의 기초 자료로 사용될 것이라 사료된다.

\section{REFERENCES}

1. Kim MJ, Kim SH. The effect of cervical traction on pain \& symptom for patients with cervical pain. Kor Acad Ortho Man Phys Ther. 2001;7(1): 67-75.

2. Cassidy J, Carroll L, Kristman V. The annual incidence and course of neck pain in the general population: a population-based cohort study. Pain. 2004;112:267-73.

3. Mekhora K, Liston CB, Nanthavanij S et al. The effect of ergonomic intervention on discomfort in computer users with tension neck syndrome. Int J Industrial Ergonomics. 2000;16:367-70.

4. Kim KW, Lee JS. The clinical effects of chuna treatment in painful neck disease. Journal of korea CHUNA manual medicine. 2000;1(1):67-82.

5. Lee HJ, Leslie L, Nicholson et al. Cervical range of motion association with sub-clinical neck pain. PNF \& Mov. 2003;1(1):43-57.

6. Oh SG, Yoo SH. Biomechanical changes in lower quadrant after manipulation of low back pain patients with sacroiliac joint dysfunction. J Kor Phys Ther. 2001;8(1):167-80.

7. Dvord J, Valach L, Schmdt S. Cervical spine injuries in Swizerland. Manual Med. 1989;4:7-16.

8. Go SM. Study on the connection between muscle and cosmetic deformation. Sungshin University. Dissertation of Master's Degree. 2007.

9. Seo DC. Effect of myofascial release on the alleviation of upper trapezius muscle myofascial pain of piano player. Konkuk University. Dissertation of Master's Degree. 2010.

10. Song HS. A Study on the Changes in Foot Shape after Caring Back Muscle Fascia. Konyang University. Dissertation of Master's Degree. 2010.

11. Kim SY. The effect of myofascial release and stone therapy on the upper trapezius muscle and emotional indicators. Kwangju Women's University. Dissertation of Master's Degree. 2013. 
12. Simons D, Travell J, Simons L. Myofascial pain and dysfunction: The Trigger Point Maunal. Baltimore, Lippincott Williams\& Wilkins.1999; 12-9.

13. Punnett L, Robin JM, Wegman DH et al. Soft tissue disorders in the upper limbs of female garment workers. Scand J work Environ Health. 1985;11:417-25.

14. Typaldos S. Clinical and theoretical application of the fascial distortion model within the practice of medicine and surgery. 4thed. Bangor, Typaldos Publishing Co, 2002:3-60.

15. MacDonald GZ, Penney MD, Mullaley ME et al. An acute bout of selfmyofascial release increases range of motion without a subsequent decrease in muscle activation or force. J Strength Cond Res. 2013;27:81221.

16 Hwang Bo PN. Psychological and physical effects of schroth and pilates exercise on female high school students with idiopathic scoliosis. J Kor Phys Ther. 2016;28(6):364-68.

17. Jeon JK. A Case Study on the application of myofascial release on plantar fasciitis. Kor Acad Ortho Man Phys Ther. 2003;9(2):93-5.

18. Manheim. The myofascial release manual. second edition. NJ, SLACK Incorporated.1994;11-22.

19. MacDonald G, Penney M, Mullaley Met al. An acute bout of self-myofascial release increases range of motion without a subsequent decrease in muscle activation or force. The Journal of Strength \& Conditioning Research. 2013;27:812-21.

20. Kim JS. Changes of flexibility and plasma catecholamine by myofascial release approach. Jour. of KoCon. a. 2012;12:214-21.

21. Saghaei, M. (2004). Random allocation software for parallel group randomized trials. BMC Med. Res. Methodol. 2004;4(26):1471-2288.

22. Maduri A, Wilson S. Lumbar position sense with extreme lumbar angle. J Electromyogr Kinesiol. 2009;19(4):607-13.

23. Lam SS, Jull G, Treleaven J. Lumbar spine kinesthesia in patients with low back pain. J Orthop Sports Phys Ther. 1999;29(5):294-99.
24. Brodie D, Burnett J, Walker J. Evaluation of low back pain by patient questionnaires and therapist assessment. J Orthop Sports Phys Ther. 1990;11:519-29.

25. Park JW. Joint position sense, reposition test, shoulder pain, range of motion. KSR. 2007;18(6):443-50.

26. Jensen $M$, Chen C, Brugger A. Interpretation of visual analogue scale rating and change score: a reanalysis of two clinical trials of post operative pain. J Pain. 2003;4(7):407-14.

27. Wessely S, Hotopf M. Is fibromyalgia a distinct clinical entity? Historical and epidemiological evidence. Best Practice \& Research Clinical Rheumatology. 1999;13(3):427-36.

28. Hagberg M, Wegman D. Prevalencerates and oddsratios of shoulder neck disease in different occupational group. Br J Ind Med. 1987;44(9): 602-10.

29. Lee MH, Song JM, Kim JS. The effect of neck exercises on neck and shoulder posture and pain in high school students. J Kor phys Ther. 2011;23(1):29-35.

30. Nam SG, Jun IS, Huh HM et al. Assessment of intramuscular stimulation in patients with myofascial pain syndrome using thermography. Korean J Pain. 2003;16(1):54-9.

31. Lee JH, Kang DH, Kang JI. The effects of myofascial relaxation on blood flow velocity of the cranial artery and pain level in cervicogenic headache patients. J Kor Phys Ther. 2010;22(5):49-56.

32. Barnes JF, Smith G. The body is a self correcting of vertebral muscle. Spine. 1987;16

33. Park YN, Bae YS. Change of pain and breathing function following Kinesio taping of myofascial Pain in sternocleidomastoid muscle. J Kor Phys Ther. 2014;26(5):302-7.

34. Park HJ, Oh TY. Effects of closed chain exercise on activities of shoulder girdle muscles in 60's. J Kor Phys Ther. 2015;27(4):246-51.

35. Kim JM. Neuroanatomy \& neurophysiology. 3rd ed. Seoul, Jungdam Media, 2009:77-88. 